\title{
PENGARUH LATIHAN BALL SLAMS TERHADAP KEMAMPUAN DAYA LEDAK OTOT LENGAN ATLET BULUTANGKIS PB. KAKAK TUA KOTO BARU KABUPATEN DHARMASRAYA
}

\author{
Bagus Santoso ${ }^{1}$, Apri Agus ${ }^{2}$ \\ Jurusan Kesehatan dan Rekreasi, Universitas Negeri Padang, \\ Padang, Indonesia \\ baqussantoso04061996@gmail.com
}

\begin{abstract}
This Study aims todetermine the effect of Ball Slams training on the explosive power of PB badminton athlete's arm muscles Kakak Tua Koto Baru District Dharmasraya. This is because the explosive power of the badminton athlete's arm is not yet maximal PB. Kakak Tua Koto Baru District Dharmasraya. Type research that is used in researchthis is an experiment apparent. The population in penelition is numbered as 25 people athlete. Mechanical taking sampel used purposive sampling, with samples of as many as 10 people athlete men aged 14-17 years. Data collection techniques by way of two hand medicine ball put. Then data in the analysis of the test statistic difference mean arithmetic ( $t$ test) in the level of significance $\alpha=0: 05$. Based hacyl research that has been done turns Exercise ball slams give effect to increase the ability of power explosive muscular arm athlete badminton PB. Kakak Tua Koto Baru District Dharmasraya. It is able view of the difference in value of the averagein the test beginning at 5,43 and after a given treatment obtained values an average of 5.86, there of 0.43 meters, as well as evidenced by the value of $t$ arithmetic $=17.917>t$ table $=2.262$ with $\alpha=0,05$
\end{abstract}

\section{Keywords: Ball Slams Training, Arm muscle explosive power, Badminton}

\begin{abstract}
Abstrak
Penelitian ini bertujuan untuk mengetahui pengaruh latihan Ball Slams terhadap kemampuan daya ledak otot lengan atlet bulutangkis PB. Kakak Tua Koto Baru Kabupaten Dharmasraya. Hal ini dikarenakan belum maksimalnya daya ledak otot lengan atletbulutangkis PB. Kakak Tua Koto Baru Kabupaten Dharmasraya. Dalam penelitian ini digunakan jenis penelitian eksperimen semu. Adapun populasi dalam penelitioan ini berjumlah sebanyak 25 orang atlet. Teknik pengambilan sampel menmggunakan purposive sampling, dengan sampel sebanyak 10 orang atlet putra umur 14-17 tahun. Teknik pengambilan datanya dengan cara two hand medicine ball put. Kemudian data di analisis dengan uji statistik beda rerata hitung (t-test) pada taraf signifikansi $\alpha=$ 0.05. Dari hasil penelitian yang telah dilakukan ternyata Latihan ball slams
\end{abstract}


E-ISSN 2655-2515

P-ISSN 2655-1802

memberikan pengaruh terhadap peningkatan kemampuan daya ledak otot lengan atlet bulutangkis PB. Kakak Tua Koto Baru Kabupaten Dharmasraya. Hal ini dapat terlihat dari perbedaan nilai rata-rata pada tes awal sebesar 5,43 dan setelah diberikan perlakuan diperoleh nilai rata-rata sebesar 5,86 , ada peningakatan sebesar 0,43 meter, serta dibuktikan dengan nilai $t_{\text {hitung }}=17,917>t_{\text {tabel }}=2,262$ dengan $\alpha=0.05$

Kata kunci: Latihan Ball Slams, Daya ledak otot lengan, Bulutangkis

\section{Pendahuluan}

Olahraga yang banyak digemari oleh masyarakat terutama anak-anak , remaja, bahkan orangtua adalah olahraga bulutangkis. Karena olahraga ini merupakan salah satu olahraga prestasi yang banyak dibina dan disukai banyak kalangan. Salah satu klub yang dibina adalah PB. Kakak Tua Koto Baru Kabupaten Dharmasraya. Tujuan dari pembinaan ini adalah untuk mendapatkan prestasi yang baik.

Dalam pembinaan untuk meraih sebuah prestasi bermain bulutangkis tidak terlepas dari faktor kemampuan fisik, penguasaan teknik dan mental. Menurut Syafruddin (2011:57) bahwa "Keberhasilan prestasi yang ditunjukkan/ditampilkan seorang atlet dalam suatu kompetisi terutama ditentukan dan dipengaruhi oleh kemampuan atau potensi atlet itu sendiri secara terpadu, baik kemampuan fisik, teknik, taktik, dan mental".

Dalam permainan bulutangkis persiapan kondisi fisik sangat penting untuk meningkatkan dan memantapkan kualitas teknik. Kondisi fisik adalah kemampuan fisik atau kesanggupan tubuh seseorang dalam bekerja atau berolahraga. Keterampilan teknik dasar bulutangkis penting untuk dimiliki bagi seseorang pemain, karena hal itu merupakan gambaran keterampilan yang ia miliki. Artinya semakin baik penguasaan dalam cabang olahraga bulutangkis, maka semakin tinggi keterampilan teknik yang dimilikinya. Teknik yang paling dominan dalam permainan bulutangkis adalah teknik pukulan.

Menurut Khairuddina (2000:120-133) secara garis besar teknik pukulan dalam permainan bulutangkis adalah : "(1) Servis, (2) Lob, 3) Chop, 4) Smash, 5) Drive dan 7) Net shot".

Berdasarkan informasi dari pelatih, club ini sering mengikuti iven-iven bulutngkis, tapi prestasinya belum maksimal. Berdasarkan pengamatan dan observasi yang penulis lakukan di lapangan terhadap atlet bulutangkis PB. Kakak Tua Koto Baru Kabupaten Dharmasraya, penulis melihat daya ledak otot lengan pemain belum maksimal, hal ini terlihat ketika melakukan pukulan, terutama sekali pukulan servis panjang dan smash. Sewaktu pemain melakukan servis panjang, 
pukulan yang dilakukan pemain tidak keras dan tidak tinggi sehingga tidak sampai keujung lapangan, ketika pemain melakukan smash, pukulan yang dilakukan pemain tidak kuat, tidak tajam serta kurang terarah sehingga lawan mudah mengembalikan shuttlecock, kondisi ini tentunya akan menguntungkan bagi pihak lawan untuk memperoleh poin. Banyak faktor yang mempengaruhi kemampuan teknik memukul dalam permainan bulutangkis salah satunya kondisi fisik diantaranya, daya ledak otot lengan. Banyak faktor yang mempengaruhi daya ledak otot lengan, diantaranya panjang lengan dan komposisi otot.

Berdasarkan uraian di atas, adapun masalah yang bisa diteliti yaitu, bahwa dalam melakukan teknik pukulan, terutama sekali pukulan servis panjang dan smash dibutuhkan unsur daya ledak otot lengan. Semakin bagus daya ledak otot maka semakin kuat pukulannya. Banyak metode yang digunakan untuk melatih meningkatkan daya ledak otot lengan ini, diantaranya dengan latihan Ball Slams.

Latihan ball slams adalah bentuk latihan beban yang dipakai untuk meningkatkan daya ledak otot lengan. Berdasarkan yang telah diuraikan, peneliti tertarik untuk meningkatkan dayua ledak otot lengan atlet bulutangkis PB. Kakak Tua Koto Baru Dharmasraya menggunakan latihan ball slams.

\section{Metode}

Jenis penelitian yang digunakan adalah eksperimen semu, dengan pengambilan data dengan cara two hand medicine ball put. Data kemudian dianalisis menggunakan uji statistik beda rerata hitung (t-test) pada taraf signifikansi $\alpha=0.05$. 


\section{Hasil Penelitian}

\section{Deskripsi Data}

\section{Daya Ledak Otot Lengan Sebelum diberi Perlakuan Latihan Ball Slams}

Dari 10 orang atlet bulutangkis PB. Kakak Tua Koto Baru Kabupaten Dharmasraya, tidak ada atlet yang memiliki daya ledak otot lengan dengan klasifikasi baik sekali, 3 orang (30\%) atlet memiliki daya ledak otot lengan klasifikasi baik, 4 orang (40\%) atlet memiliki daya ledak otot lengan klasifikasi sedang, 3 orang (30\%) atlet memiliki daya ledak otot lengan klasifikasi kurang dan tidak ada atlet yang memiliki daya ledak otot lengan dengan klasifikasi kurang sekali. Secara keseluruhan daya ledak otot lengan atlet bulutangkis PB. Kakak Tua Koto Baru Kabupaten Dharmasraya berada pada klasifikasi "Sedang" yang dibuktikan dengan nilai rata-rata 5,43. Untuk jelasnya dapat dilihat gambar 2 .

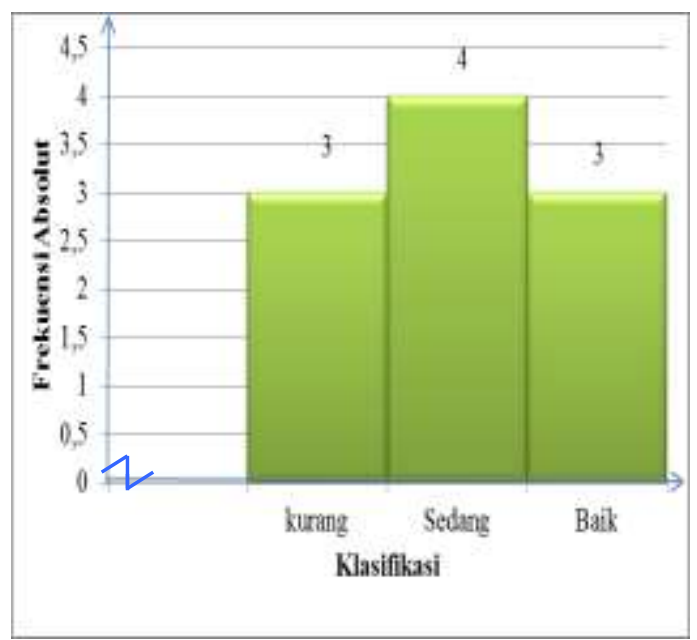

Gambar 2. Histogram daya Ledak otot Lengan Sebelum Latihan Ball Slams

\section{Daya ledak otot Lengan Setelah diberi Perlakuan Latihan Ball Slams}

Dari 10 orang atlet bulutangkis PB. Kakak Tua Koto Baru Kabupaten Dharmasraya, tidak ada atlet yang memiliki daya ledak otot lengan dengan klasifikasi baik sekali, 4 orang (40\%) atlet memiliki daya ledak otot lengan klasifikasi baik, 3 orang $(30 \%)$ atlet memiliki daya ledak otot lengan klasifikasi sedang, 2 orang (20\%) atlet memiliki daya ledak otot lengan klasifikasi kurang dan 1 orang (10\%) atlet memiliki daya ledak otot lengan dengan klasifikasi kurang sekali. Secara keseluruhan daya ledak otot lengan atlet bulutangkis PB. Kakak Tua Koto Baru Kabupaten Dharmasraya berada pada klasifikasi "Sedang" yang dibuktikan dengan nilai rata-rata 5,86. Untuk jelasnya dapat dilihat gambar 3. 


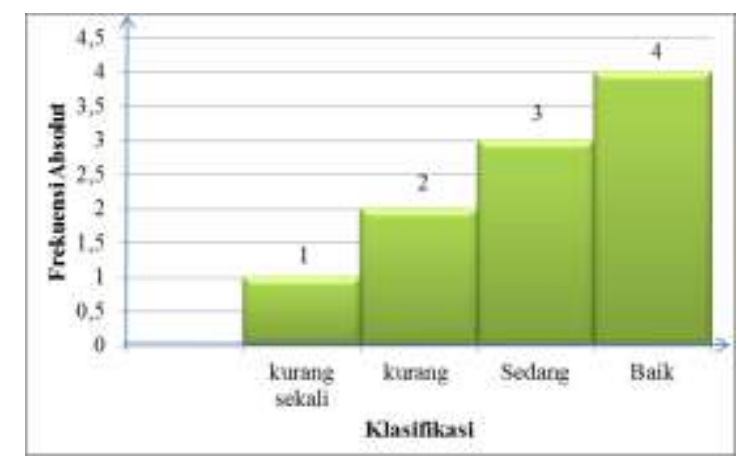

\section{Gambar 3. Histogram daya Ledak otot Lengan Sesudah Latihan Ball slams}

\section{Uji Normalitas}

Hasil dari uji normalitas variabel dapat dilihat pada tabel 1.

\section{Tabel 1. Uji Normalitas Data Penelitian}

\begin{tabular}{|l|l|c|c|c|c|}
\hline \multicolumn{2}{|c|}{ Variabel } & N & Lo & Ltabel & Keterangan \\
\hline $\begin{array}{l}\text { Daya } \\
\text { Ledak } \\
\text { Otot } \\
\text { Lengan }\end{array}$ & $\begin{array}{l}\text { Sebelum } \\
\text { Perlakukan }\end{array}$ & 10 & 0,1364 & 0,258 & Normal \\
\cline { 2 - 6 } & $\begin{array}{l}\text { Setelah } \\
\text { Perlakuan }\end{array}$ & 10 & 0,1106 & 0,258 & Normal \\
\hline
\end{tabular}

Berdasarkan tabel 1 di atas, ternyata hasil Liliefort, menunjukan bahwa Lo < Ltabel, dengan demikian dapat disimpulkan bahwa kedua data, yaitu daya ledak otot lengan selum dan sesudah perlakukan latihan ball slams berdistribusi normal dan layak untuk dilanjutkan

\section{Uji Homogenitas}

Uji homogenitas dilakukan dengan uji varians. Artinya varians data populasi sama, data dalam keadaan homogen. Adapun rangkuman hasil pengujian kesamaan varians tersebut dapat dilihat pada tabel 2 :

Tabel 2. Uji Homogenitas

\begin{tabular}{|l|c|l|l|}
\hline Variabel & $\mathbf{F}_{\text {hitung }}$ & $\mathbf{F}_{\text {tabel }}$ & $\begin{array}{l}\text { Kesimpula } \\
\mathbf{n}\end{array}$ \\
\hline $\begin{array}{l}\text { Daya Ledak } \\
\text { Otot Lengan }\end{array}$ & 1 & 3,18 & Homogen \\
\hline
\end{tabular}

Berdasarkan tabel 2 , ternyata $F_{\text {hitung }}(1)<F_{\text {tabel }}(3,18)$, maka disimpulkan bahwa kedua varians tersebut homogen. Dan kedua kelompok sampel tersebut berasal 
E-ISSN 2655-2515

P-ISSN 2655-1802

dari populasi yang homogen.

\section{Uji Hipotesis}

Hipotesis yang diajukan di dalam penelitian ini adalah terdapat pengaruh latihan ball slams terhadap kemampuan daya ledak otot lengan atlet bulutangkis PB. Kakak Tua Koto Baru Kabupaten Dharmasraya.

Berdasarkan hasil analisis koefisien yang telah dibahas, diperoleh $t_{\text {hitung }}(17,917)>$ $t_{\text {tabel }}(2,262)$ pada taraf signifikasi $\alpha=0,05$. Maka Ho ditolak. Dengan demikian hipotesis yang diajukan dapat dibuktikan. Artinya latihan ball slams berpengaruh terhadap peningkatan kemampuan daya ledak otot lengan atlet bulutangkis PB. Kakak Tua Koto Baru Kabupaten Dharmasraya

\section{PEMBAHASAN}

Berdasakan hasil penelitian yang telah diuraikan sebelumnya dapat diketahui bahwa latihan ball slams dengan pemberian latihan sebanyak 18 kali perlakukan dengan frekuensi 3 kali seminggu, ternyata memberikan pengaruh secara signifikan terhadap peningkatan kemampuan daya ledak otot lengan atlet bulutangkis PB. Kakak Tua Koto Baru Kabupaten Dharmasraya.

Terdapatnya peningkatan kemampuan daya ledak otot lengan dengan latihan ball slams ini mungkin disebabkan oleh cara pelaksanaannya, selain itu dalam latihan bola yang dilempar adalah seberat $2 \mathrm{~kg}$, Jumlah latihan dilakukan $18 \mathrm{kali}$, dengan frekuensi 3 kali seminggu dengan penambahan set dalam latihan serta repetisinya disesuaikan dengan kemampuan maksimum yang dimiliki pemain, sehingga dengan latihan tersebut memberikan efek terhadap peningkatan kemampuan daya ledak otot lengan atlet bulutangkis PB. Kakak Tua Koto Baru Kabupaten Dharmasraya. Dengan demikian perlu kiranya menjadi perhatian pelatih bulutangkis PB. Kakak Tua Koto Baru Kabupaten Dharmasraya untuk dapat meningkatkan lagi daya ledak otot lengan pemain, diantaranya memberikan bentuk latihan ball slams secara terprogram dan secara kontinu, karena dari hasil penelitian bentuk latihan ini dapat meningkatkan daya ledak otot lengan.

\section{SIMPULAN}

Berdasarkan hasil penelitian tentang pengaruh latihan ball slams terhadap kemampuan daya ledak otot lengan atlet bulutangkis PB. Kakak Tua Koto Baru Kabupaten Dharmasraya, dapat diambil kesimpulan bahwa : Latihan ball slams memberikan pengaruh terhadap peningkatan kemampuan daya ledak otot lengan atlet bulutangkis PB. Kakak Tua Koto Baru Kabupaten Dharmasraya, hal 
ini dapat dilihat dari perbedaan nilai rata-rata pada tes awal sebesar 5,43 dan setelah diberikan perlakuan diperoleh nilai rata-rata sebesar 5,86 , ada peningakatan sebesar 0,43 meter, serta dibuktikan dengan nilai $t_{\text {hitung }}=17,917>t_{\text {tabel }}=2,262$ dengan $\alpha=0.05$.

\section{DAFTAR PUSTAKA}

Apri, Agus. 2012. Olahraga Kebugaran Jasmani. Padang : Sukabina Press David Sandler, McNeely. 2007. Power Plyometrics The Complete Program. Singapore : Meyer \& Meyer Sport Hermawan, Aksan. 2013. Mahir Bulutangkis. Bandung : Nuansa Cendikia Khairuddin. 2000. Pedoman Permainan Buluntangkis. Padang FIK UNP M Tohar, 1992. Olahraga Pilihan Bulutangkis. IKIP Semarang. Semarang Muhajir. 2007. Pendidikan Jasmani Olahraga dan Kesehatan. Erlangga : Jakarta Syafruddin. 2011. Ilmu Kepelatihan Olahraga. Padang : FIK UNP. UNP Press. 